\title{
Research Progress on Pathogenesis and Intervention Measures of Depression
}

\author{
Yun Shang*, Beibei Ge, Xiaolei Zhang \\ Wuhan Sports University, Wuhan 430079, Hubei Province, China \\ *Corresponding author: Yun Shang, 1134060575@qq.com
}

\begin{abstract}
With the wide spread of the epidemic, the long-term closed lifestyle and the sharp reduction of physical activities, many people have mental health problems such as panic, anxiety and depression. At present, there are few studies on the effect of exercise on depression. Therefore, the study selected exercise intervention therapy and other intervention methods to evaluate the intervention effect of depression, and explored the effect of exercise intervention by evaluating depression scale and effective indicators. Hope this can provide a new idea for exercise intervention as an adjunctive therapy for depression on drug treatment.
\end{abstract}

Keywords: Epidemic; Depression; Exercise intervention

Publication date: September 2021; Online publication: September 30, 2021

\section{Introduction}

Depression is also called depressive disorder, which is a mental disease characterized by various clinical manifestation, complex causes and persistent depression. The main symptoms are depressed mood, loss of fun, easy to be sad, sleep disorder and even suicidal tendency in severe cases ${ }^{[1]}$. Therefore, it is particularly important to pay attention to people's mental health and reduce the prevalence of depression during the epidemic. Pathogenesis and clinical treatment of depression has attracted more and more attention, and there is still big dispute existed in the effectiveness of various therapies. In this paper, the key words are: Epidemic, depression, pathogenesis, exercise intervention and so on are the keywords. Relevant literatures included in the data base of CNKI, PubMed, Web of Science were searched to review the pathogenesis and different intervention methods' effectiveness of depression, so that we can put forward effective intervention measures for depression treatment.

\section{Pathogenesis of depression}

Depression is a chronic syndrome characterized by low mood, pessimism, and cognitive and sleep disorders. It is characterized by high morbidity, high suicide rate, low consultation rate and low treatment rate, etc. Current theories on the pathogenesis of depression mainly include the following (Figure 1).

\subsection{Abnormal neurotransmitters and their receptors}

According to the earliest "monoamine" theory, depression is mainly due to the abnormality of neurotransmitters and their receptors, such as the decrease of 5-HT, dopamine and norepinephrine (NE) levels in cerebrospinal fluid of patients with depression, the disorder of central nervous system, the disorder of norepinephrine (NE) system and the significant decrease of NE in hypothalamus. The expression activity of NE receptor was up-regulated and the number increased, leading to receptor hypersensitivity. The use of drugs that deplete NE can induce depression, suggesting that NE dysfunction plays an important role in 
the occurrence of depression.

\subsection{Neurodegeneration and endocrine disorder}

Imaging studies have found that patients with depression have neurodegeneration of marginal structure dominated by hippocampus and reduced hippocampal volume, which may be the pathological basis of cognitive impairment in patients with depression. Depression is also closely related to neuroendocrine. The hypothalamic-pituitary-adrenal axis (HPA) in patients with depression is hyperfunctioning, and the serum cortisol concentration is increased, which also plays an important role in the occurrence of depression.

\subsection{Increased inflammatory cytokines}

Immune molecules play an important role in the pathogenesis of depression. A certain degree of inflammation is often accompanied by depression, resulting in the increase of proinflammatory cytokines, such as tumor necrosis factor and interleukin-1 secretion, resulting in the decrease of 5-HT level in cerebrospinal fluid. Therefore, the increase of inflammatory factors has also become an important indicator of depression.

\subsection{Abnormal brain-derived neurotrophic factor}

Abnormality of brain-derived neurotrophic factor (BDNF); BDNF is involved in the plasticity of neurons in some brain regions. Many studies have shown that the concentration of BDNF in patients with depression is lower than that in ordinary people, and will gradually increase after treatment. Therefore, the abnormality of BNNF is also a key factor leading to depression.

\subsection{Epigenetic mechanism}

More and more evidence show that epigenetic can regulate the risk of depression. Strong and long-term environmental stimulation will cause changes in chromosome structure, resulting in changes in hippocampal morphology and structure and loss of neuronal function. Hippocampal formation function decreases and neuronal function regresses, which will lead to depression.

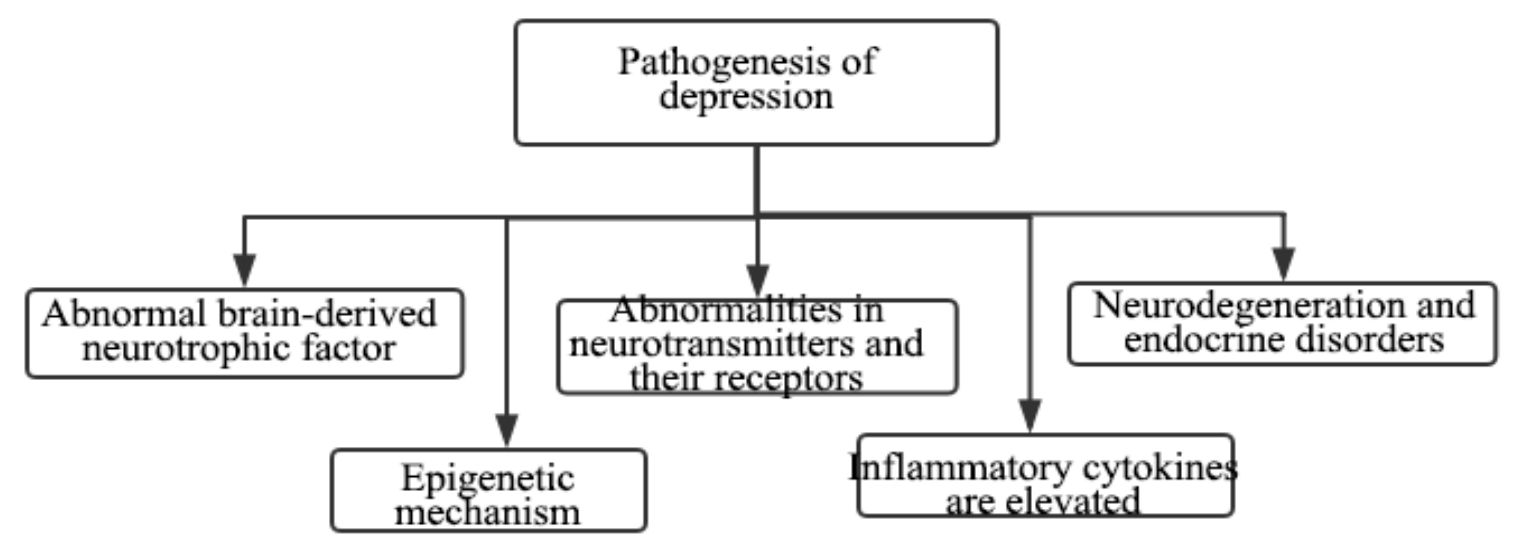

Figure 1. Several theories on the pathogenesis of depression

\section{Interventions}

\subsection{Drug interventions}

For a long time, the treatment of depression mainly includes drug therapy and non-drug intervention therapy. At present, drug treatment is a common means of depression. Although it can effectively improve the physical symptoms of patients, it has the disadvantages of high recurrence rate and large side effects. Antidepressants take effect slowly. Generally, the symptoms can only appear after taking drugs for more 
than 6 weeks (Table 1.), and the cognitive improvement of patients has not been carried out.

Table 1. Effects of different drugs on depression

\begin{tabular}{|c|c|c|c|c|c|c|}
\hline Author & Interventions & $\mathbf{N}$ & Cycle & $\begin{array}{l}\text { Adverse } \\
\text { reaction }\end{array}$ & $\begin{array}{c}\text { Marked } \\
\text { effective } \\
\text { rate } \\
\end{array}$ & Effect \\
\hline Miao Pan & Clomipramine & 30 & 6 months & $33 \%$ & $40 \%$ & $\begin{array}{l}\text { Adverse reactions } \\
\text { appear; } \\
\text { efficacy is not } \\
\text { obvious }{ }^{[2]} \text {; }\end{array}$ \\
\hline Hongjie Wang & Trazodone & 40 & 8 weeks & $15 \%$ & $95 \%$ & $\begin{array}{l}\text { Adverse reactions } \\
\text { appear; It is effect } \\
\text { on the whole }{ }^{[3]} \text {. }\end{array}$ \\
\hline Luping Zhao & Reboxetine & 42 & 8 weeks & 16 cases & $76.1 \%$ & $\begin{array}{l}\text { Adverse reactions } \\
\text { appear; It has high } \\
\text { drug compliance } \\
{[4] \text {. }}\end{array}$ \\
\hline Hongli Li & Sertraline & 40 & 6 weeks & $17.5 \%$ & $85 \%$ & $\begin{array}{lr}\text { Adverse reactions } \\
\text { appear; } \\
\text { efficacy is slow }{ }^{[5]} \text {. }\end{array}$ \\
\hline Zhiyong Ren & Duloxetine & 55 & 6 weeks & $16 \%$ & $87.2 \%$ & $\begin{array}{l}\text { Adverse reactions } \\
\text { appear; It has low } \\
\text { drug compliance } \\
{[6] \text {. }}\end{array}$ \\
\hline Suhua Meng & Mirtazapine & 41 & 6 weeks & $21.95 \%$ & $70.73 \%$ & $\begin{array}{l}\text { Adverse reactions } \\
\text { appear }{ }^{[7]} ;\end{array}$ \\
\hline Zhiyong Ren & Agomelatine & 55 & 6 weeks & $13 \%$ & $89 \%$ & $\begin{array}{l}\text { It has fatal } \\
\text { hepatotoxic } \\
\text { adverse reactions } \\
{[6] \text {; }}\end{array}$ \\
\hline $\begin{array}{l}\text { Tianliang } \\
\text { Zhang }\end{array}$ & Bupropion & 45 & 8 weeks & $52.7 \%$ & $82.2 \%$ & $\begin{array}{l}\text { Adverse reactions } \\
\text { appear; It has side } \\
\text { effects on stomach } \\
{[8]}\end{array}$ \\
\hline
\end{tabular}

\subsection{Non drug interventions}

\subsubsection{Psychological intervention}

Psychological intervention therapy is a kind of psychotherapy. Different from other therapies, doctors mainly affect patients' psychological activities through language. As an auxiliary form of drug therapy, this treatment method is gradually used at home and abroad. This therapy has potential therapeutic value for the rehabilitation of depression. A large number of studies show that simple psychotherapy is effective in the acute stage of depression. At the same time, the professionalism of employees, the universality of treatment costs and the recurrence of depressive symptoms all make psychological intervention therapy not popular. (Table 2.) 
Table 2. Effects of non-drug intervention on depression

\begin{tabular}{|c|c|c|c|c|c|}
\hline Author & $\begin{array}{l}\text { Intervention } \\
\text { mode }\end{array}$ & $\begin{array}{l}\text { Measurement } \\
\text { method }\end{array}$ & $\begin{array}{c}\text { Pre- } \\
\text { intervention } \\
\text { score } \\
\end{array}$ & $\begin{array}{c}\text { Post- } \\
\text { intervention } \\
\text { score } \\
\end{array}$ & Effect \\
\hline Hui Wu & $\begin{array}{l}\text { Psychological } \\
\text { intervention }\end{array}$ & $\begin{array}{l}\text { PHQ-9 Depression } \\
\text { Scale }\end{array}$ & $15.43 \pm 2.73$ & $5.13 \pm 1.26$ & $\begin{array}{l}\text { Effective in the early } \\
\text { stage; Prevention and } \\
\text { control first; } \\
\text { Mitigation }\end{array}$ \\
\hline Shuya Wang & $\begin{array}{l}\text { Psychological } \\
\text { intervention }\end{array}$ & LES life events scale & $2.45 \pm 0.49$ & $1.16 \pm 0.36$ & $\begin{array}{l}\text { Effective in the early } \\
\text { stage; } \\
\text { depression; } \\
\text { Mitigation }\end{array}$ \\
\hline Jianfang Xie & $\begin{array}{l}\text { Psychological } \\
\text { intervention }\end{array}$ & $\begin{array}{l}\text { Hamilton depression } \\
\text { scale }\end{array}$ & $28.6 \pm 3.2$ & $11.2 \pm 2.1$ & $\begin{array}{l}\text { Drug binding; } \\
\text { Recurrent; Mitigation } \\
{[15]}\end{array}$ \\
\hline Jian Wang & $\begin{array}{l}\text { Psychological } \\
\text { intervention }\end{array}$ & $\begin{array}{c}\text { Beck Depression } \\
\text { Questionnaire (BDI) }\end{array}$ & 45 points & 0 points & $\begin{array}{l}\text { Overall effectiveness; } \\
\text { Individual cases }{ }^{[16]} \text {; }\end{array}$ \\
\hline Shunxi Chen & $\begin{array}{l}\text { Psychological } \\
\text { intervention }\end{array}$ & SDS scale & 59 points & 54 points & $\begin{array}{l}\text { Mild depression; The } \\
\text { effect is not obvious } \\
{[17]}\end{array}$ \\
\hline Haihua Zhang & Music therapy & $\begin{array}{l}\text { Hamilton depression } \\
\text { scale }\end{array}$ & $22.30 \pm 2.59$ & $3.60 \pm 1.67$ & $\begin{array}{l}\text { Mild or moderate } \\
\text { depression; Partially } \\
\text { valid }\end{array}$ \\
\hline Tao Jin & Music therapy & $\begin{array}{l}\text { Hamilton depression } \\
\text { scale }\end{array}$ & $24 \pm 8$ & $8 \pm 5$ & $\begin{array}{l}\text { Medical assistance; } \\
\text { Small sample size }\end{array}$ \\
\hline Ping Tong & $\begin{array}{l}\text { Behavioral } \\
\text { analysis } \\
\text { therapy }\end{array}$ & $\begin{array}{l}\text { Hamilton depression } \\
\text { scale }\end{array}$ & $27.8 \pm 5$ & $9.6 \pm 3.7$ & $\begin{array}{l}\text { Limited applicability } \\
\text { and investigation } \\
\text { indicators }\end{array}$ \\
\hline$\frac{\text { M.Zeme }}{\text { stani }}$ & $\begin{array}{l}\text { Behavioral } \\
\text { activation } \\
\text { therapy }\end{array}$ & $\begin{array}{l}\text { Beck Depression } \\
\text { Inventory }\end{array}$ & $28.77 \pm 3.37$ & $15.38 \pm 2.25$ & $\begin{array}{l}\text { Small sample size; } \\
\text { Mild or moderate } \\
\text { depression; High } \\
\text { recurrence rate }\end{array}$ \\
\hline
\end{tabular}

\subsubsection{Music intervention}

The therapeutic effect of music therapy on depression has also been studied by scholars. Depression is mostly seen in liver Qi stagnation. Music therapy can alleviate liver depression and effectively improve the mood and quality of life of depressed patients ${ }^{[9,10]}$. It is convenient, effective, safe and cheap. It is more and more used in clinical treatment, and commonly used in moderate and mild depression. However, it is only effective for some patients, and the therapeutic effect of music therapy alone is limited, It needs to be combined with drug treatment to show good results ${ }^{[11]}$.

\subsubsection{Behavioral activation intervention}

Behavioral activation therapy refers to activating patients' behavioral activities by providing patients with activities with a high sense of pleasure and control, increasing patients' sense of participation and improving their positive attitude towards life. Through behavioral activation therapy, choosing the lifestyle patients 
like can effectively improve the symptoms of moderate and mild depression ${ }^{[12]}$. Some studies have shown that behavioral activation therapy is an effective and relatively simple treatment method in theory. Its mechanism is based on the principle of operant conditioning to re-establish the active contact between the patient and the outside world. The treatment strategy is to establish a regular life and change the state of long-term meditation.

\subsection{Exercise intervention}

At present, antidepressants are mostly used in the treatment of depression. With the adverse reactions, drug dependence and drug compliance caused by antidepressants, people have to find new treatment measures with safety, effectiveness and feasibility. In contrast, the effect of exercise therapy on the effective relief of depression is equivalent to that of drug treatment, and it is a treatment method without side effects and environmental protection for health ${ }^{[19]}$. (Table 3.)

\subsubsection{Team sports}

Exercise intervention therapy refers to a physical training method that uses instruments, bare hands or the patient's own strength to restore the patient's whole body or local motor function and sensory function through a certain exercise mode. Studies have shown that patients with depression need more support, cooperation and atmosphere of exercise, and regular cooperative exercise can effectively improve the state of depression ${ }^{[20]}$. Yanchun Peng et al. has made research on improvement effect of depression through different forms of exercise, and the outcome shows: Basketball, volleyball, football, jogging and other forms of exercise can regulate mental health to varying degrees, and there are no adverse reactions. Some studies have described the effect of short cycle aerobic exercise on depressive symptoms and cardiopulmonary function, and adopted self-made treadmill exercise prescription: A total of 3 weeks of aerobic exercise intervention has been carried out and the results showed that aerobic exercise could significantly improve the symptoms of depression. Emotion is directly related to the degree of depression. Pleasant activities help to alleviate depressive symptoms. Regular Latin dance exercise shows that rhythmic music and medium-intensity physical activities have a significant effect on improving patients' negative emotions ${ }^{[21]}$. Regular physical activity can help relieve symptoms of depression and anxiety and boost mood. Through 10 weeks of yoga practice, depressive psychological disorders, mood, anxiety and sleep disorders of the patients with depression have been significantly improved.

\subsubsection{Taijiquan sports intervention}

Taijiquan requires the consistency of speed, movement and the group. A 16 week Taijiquan training study of 36 patients showed that: The scores of depression scale, serum cortisol, and serum inflammatory factor IL-6 in the exercise group were decreased, without adverse reactions and toxic side effects, which had a positive effect on human health and depressive symptoms ${ }^{[22]}$. Kexin Ren ${ }^{[23]}$ and others believe that due to age the content of nitric oxide (NO) in human serum gradually decreases, and the activity of total nitric oxide synthase (TNOs) in serum decreases, which is easy to lead to a large number of diseases. Research finds that: Long term regular practice of Taijiquan is beneficial to improve the content of No and the activity of TNOs in serum. By practicing Taijiquan 5 times a week for 60 minutes each time for 12 weeks, it can improve human physical and mental health without adverse reactions. Qing 'an Zhou et al. ${ }^{[24]}$ received $24-$ style simple Taijiquan by professional teachers. After 24 weeks of intervention, serum tumor necrosis factor (TNF)- $\alpha$ and TNF- $\beta$ indexes were effectively reduced, and soluble tumor necrosis factor receptor (STNFR)1 and STNF-R2 levels were significantly increased. It can effectively improve people's sleep disorders and improve the activity of serum. Studies have found that the volume of frontal cortex and hippocampus in patients with depression gradually shrinks through imaging, which is closely related to the occurrence of 
depression ${ }^{[25]}$. The study on the effectiveness of health Qigong and Wuqinxi on mild depression shows that health Qigong and Wuqinxi significantly improved the scores of depression scale, prefrontal lobe and hippocampal metabolism indexes such as $\mathrm{NAA} / \mathrm{Cr}$ and $\mathrm{Cho} / \mathrm{Cr}$, without adverse reactions and toxic side effects.

Table 3. Effects of sports on depression

\begin{tabular}{|c|c|c|c|c|c|}
\hline Author & $\begin{array}{c}\text { Movement } \\
\text { mode } \\
\end{array}$ & Cycle & Duration & Effective index & Effect \\
\hline $\begin{array}{l}\text { Yanchun } \\
\text { Peng }\end{array}$ & $\begin{array}{l}\text { Basketball, } \\
\text { volleyball, } \\
\text { football and } \\
\text { so on }\end{array}$ & $\begin{array}{c}1 \text { week / } 1 \\
\text { times }\end{array}$ & $\begin{array}{l}60 \\
\text { minutes }\end{array}$ & Depression scale & $\begin{array}{l}\text { Effective improvement of } \\
\text { psychological state; None } \\
\text { Adverse reaction }\end{array}$ \\
\hline An Wen & $\begin{array}{l}\text { Treadmill } \\
\text { exercise }\end{array}$ & $\begin{array}{c}1 \text { week / } 6 \\
\text { times }\end{array}$ & $\begin{array}{c}15 \\
\text { minutes }\end{array}$ & Depression scale & $\begin{array}{l}\text { Maximal oxygen uptake } \\
\text { was effectively improved; } \\
\text { No adverse reaction }\end{array}$ \\
\hline Yi Yuan & Dance & $\begin{array}{l}1 \text { week / } 3 \\
\text { times }\end{array}$ & $\begin{array}{l}80 \\
\text { minutes }\end{array}$ & $\begin{array}{l}\text { SDS international } \\
\text { depression scale }\end{array}$ & $\begin{array}{l}\text { Effective improvement of } \\
\text { heart rate; No adverse } \\
\text { reaction }\end{array}$ \\
\hline $\begin{array}{l}\text { Wenli } \\
\text { Bao }\end{array}$ & Yoga & $\begin{array}{l}1 \text { week / } 4 \\
\text { times }\end{array}$ & $\begin{array}{l}90 \\
\text { minutes }\end{array}$ & $\begin{array}{l}\text { SDS international } \\
\text { depression scale }\end{array}$ & $\begin{array}{l}\text { Effective improvement: } \\
\text { No adverse reactions } \\
\text { appear }{ }^{[20]} \text {; }\end{array}$ \\
\hline $\begin{array}{l}\text { Jinxia } \\
\text { Chen }\end{array}$ & Taijiquan & $\begin{array}{l}1 \text { week / } 3 \\
\text { times }\end{array}$ & $\begin{array}{c}60 \\
\text { minutes }\end{array}$ & $\begin{array}{c}\text { HAMD24 } \\
\text { depression scale }\end{array}$ & $\begin{array}{l}\text { Serum cortisol and serum } \\
\text { inflammatory factor IL-6 } \\
\text { were effectively improved; } \\
\text { No adverse reactions } \\
\text { appear }{ }^{[22]} \text {; }\end{array}$ \\
\hline $\begin{array}{l}\text { Kexin } \\
\text { Ren }\end{array}$ & Taijiquan & $\begin{array}{l}1 \text { week / } 5 \\
\text { times }\end{array}$ & $\begin{array}{c}60 \\
\text { minutes }\end{array}$ & Serum NO content; & $\begin{array}{l}\text { Serum TNOs activity was } \\
\text { effectively improved; No } \\
\text { adverse reactions appear } \\
{[23] \text {; }}\end{array}$ \\
\hline $\begin{array}{l}\text { Qing'an } \\
\text { Zhou }\end{array}$ & Taijiquan & $\begin{array}{c}1 \text { week / } 2 \\
\text { times }\end{array}$ & $\begin{array}{c}60 \\
\text { minutes }\end{array}$ & $\begin{array}{l}\text { Serum TNF- } \alpha, \\
\text { TNF- } \beta \text { STNF-R1 } \\
\text { and sTNFR2 } \\
\text { levels; }\end{array}$ & $\begin{array}{l}\text { PSQI factors were } \\
\text { effectively improved; No } \\
\text { adverse reactions appear } \\
\text { [24]; }\end{array}$ \\
\hline $\begin{array}{l}\text { Xiang } \\
\text { Cheng }\end{array}$ & Wuqinxi & $\begin{array}{l}1 \text { week / } 3 \\
\text { times }\end{array}$ & $\begin{array}{c}40-60 \\
\text { minutes }\end{array}$ & Depression scale; & $\begin{array}{l}\text { The metabolic indexes } \\
\text { NAA / Cr and Cho / Cr in } \\
\text { prefrontal lobe and } \\
\text { hippocampus were } \\
\text { effectively improved; No } \\
\text { adverse reactions appear } \\
\text { [26]; }\end{array}$ \\
\hline
\end{tabular}




\section{Conclusions and advises}

(1) Commonly used drugs have certain clinical effects, but the disadvantage is that they will bring more adverse reactions to patients, such as the fatal hepatotoxic reaction caused by agomelatine, and the compliance of drug treatment is low. Therefore, drug treatment alone may not be the best way to treat depression.

(2) Psychological intervention therapy, which starts from the patient's mood, self-confidence and other spiritual aspects, gives correct guidance, positive encouragement, and helps improve the patient's psychological treatment. Psychotherapy has not been popularized. The professionalism of psychotherapists, the degree of cooperation of patients and the effectiveness of patients all make psychotherapy not popular in the treatment of patients with depression.

(3) Exercise promotes nerve regeneration function, effectively improves hippocampal nerve regeneration function and neural plasticity in the brain, and improves the body's regulatory ability. The curative effect on patients is comparable to that of drugs. Improve physical quality and mood of patients through exercise.

(4) At present, it is inconvenient to go out. Taijiquan is a kind of exercise method suitable for home practice. It pays attention to breathing, expiration and inspiration skills, emphasizes the exercise of all parts of the body, and has the health concept of internal cultivation and external practice, and pays equal attention to both inside and outside. It is a very effective fitness exercise. However, there are few reports on Taijiquan improving the mental health of patients with depression. Therefore, it is of great significance to carry out large sample clinical research to clarify the exact curative effect of Taijiquan on depression.

\section{Disclosure statement}

The author declares no conflict of interest.

\section{References}

[1] Sherina MS, Rozali A, MSS, et al., 2004, The Association of Nutritional Risk with Physical and Mental Health Problems Among Elderly in a Semi-Urban Area of Mukim Kajang, Selangor, Malaysia, MalJNutr. 10(2):149-158.

[2] Pan M, Zhang SQ, Lv LX, et al., 2016, Effects of Different Antidepressant Interventions on Halfyear Outcomes in First-episode Elderly Patients with Depression. Chinese Journal of Gerontology. 36(11): 2640-2643.

[3] Wang HJ, Ma C, 2018, Clinical Efficacy and Safety Evaluation of Escitalopram Oxalate Combined with Trazodone Hydrochloride in the Treatment of Major Depression. Women's Health Research. (20): 131-134.

[4] Zhao LP, 2014, Comparison of the Efficacy of Reboxetine and Paroxetine in the Treatment of Depression. World Journal of Sleep Medicine. 1(5): 284-286.

[5] Li HL, Wang F, 2019, Comparison of the Efficcacy of Agomelatine and Sertraline in the Treatment of First-episode Depression. Chronic Pathematology Journal. 20(08): 1192-1193.

[6] Ren ZY, Wang BH, 2018, Comparison of the Efficcacy of Agomelatine and Duloxetine in the Treatment of First-episode Depression. Chinese Remedies \& Clinics, 18(11): 1995-1997.

[7] Meng SH, Xu LX, 2019, Study on the Clinical Efficacy of Escitalopram Oxalate in the Treatment of Depression with Anxiety. Chinese And Foreign Medical Research, 17(24): 55-57.

[8] Zhang TL, Chen ZE, Sun FX, 2007, A Comparative Study of Bupropion in the Treatment of 
Depression. ChinJNervMentDis. 33(9): 524-528.

[9] VanAssche E, DeBacker JRV, 2015, Musictherapy and Depression. TijdschrPsychiatr. 57(11): 823829.

[10] Zhaok, Baizg, Boa, et al.. 2016, Asystematic Review and Meta-Analysis of Music Therapy for the Older Adults with Depression. Int Journal of Geriatr Psychiatry. 31(11):1188-1198.

[11] Jin T, Wang C, Tan XL, et al., 2011, Clinical Curative Effect Observation of Music Therapy Combined with Antidepressants in the Treatment of Depression. Chongqing Medicine. 40(17): 1703-1705.

[12] Zemestanim, Davoodii, Honarmandmm, et al., 2016, Comparative Effects of Group Meta Cognitive Therapy Versus Behaviour a Lactivation in Moderately Depressed Students. Journal of Mental Health. 25(6): 479-485.

[13] Wu H, Fu XM, Wang Dx, et al., 2018, Application of IKAP Management Mode in Psychological Intervention of Patients with Diabetes and Depression in a Hospital of Haikou City. Medicine and Society, 31(07): 46-48.

[14] Wang SY, Jin LF, Bai ZX, et al., 2018, Practice of Systematic Psychological Intervention in Alleviating Depressive Symptoms in Caregivers of Alzheimer's Disease Patients. Chinese Nursing Management. 18(02): 268-272.

[15] Xie JF, Wu LX, Liao YP, et al., 2017, Application Effect of Special Psychological Intervention in Elderly Patients with Recurrent Senile Depression. Global Traditional Chinese Medicine, 10(03): 137-138.

[16] Wang J, Wu HY, Li XX, et al., 2015, Case Analysis of Depression Based on Positive Psychological Intervention Techniques. Chongqing Medicine. 44(25): 3577-3579.

[17] Chen SX, Liu FF, 2018, Effect of "Tiaoshenkaiyu Acupuncture" Combined with Psychological Intervention on Mild Depression after Stroke and Correlation Analysis of Scale Score. Acupuncture Research. 43(01): 38-42.

[18] Tong P, Bu P, Dong LP, et al., 2019, Study on the Effect of Knowledge and Practice Analysis Therapy in the Treatment of Depression. Chinese General Practice. 22(9): 1096-1100.

[19] Kvams, Kleppecl, Nordhusih, et al., 2016, Exercise as a Treatment for Depression: A MetaAnalysis. Journal of Affective Disorders. 202: 67-86.

[20] Bao WL, Qiu LW, Wu J, et al., 2015, Study on Intervention Effect of Yoga on Depression in College and University Students. Journal of Kunming Medical University, 36(03): 169-172.

[21] Fu HP, Zhao XH, 2013, Observation on the Effect of Exercise on Patients with Depression. China Medicine and Pharmacy, 3(06): 187-188.

[22] Chen JX, Li YH, Wu YQ, et al., 2019, Effects of Taijiquan Exercise on Depression and Serum Inflammatory Factors of Female College Students. Chinese Journal of School Health, 40(07): 10651068.

[23] Ren KX, 2007, Effects of Taijiquan on the Activity of cNOS and iNOS in Serum of Middle-Aged and Elderly People. Journal of Capital University of Physical Education and Sports. (04): 59-61.

[24] Zhou QA, Wang XH, Zhu XQ, et al., 2019, Effects of Taijiquan on Sleep Quality in Patients with Chronic Insomnia Disorder. Chinese Journal of Rehabilitation Theory and Practice, 25(02): 230233.

[25] Patai EM, Gadiand G, Cooper JM, et al. 2015, Extent of Hippo Campala Trophy Predicts Degree of Deficit in Recall. Proceedings of the National Academy of Sciences. 112(41):12830-12833.

[26] Cheng X, Wang DM, Chen X, et al., 2016, Health Qigong and Wuqinxi Improve Hydrogen Proton Magnetic Resonance Spectra of Prefrontal Lobe and Hippocampus in Mildly Depressed College Students. Chinese Journal of Gerontology. 36(11): 1468-1476. 